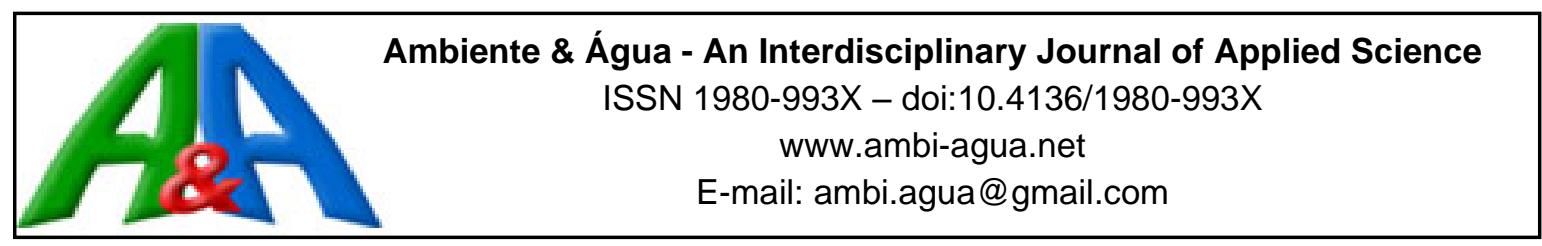

\title{
Quality of surface water and generation of sludge at water treatment plants
}

\author{
ARTICLES doi:10.4136/ambi-agua.2565
}

Received: 24 Apr. 2020; Accepted: 30 Jul. 2020

\author{
Fabiana Alves Fiore ${ }^{1^{*}(\mathbb{D})}$; Suzelei Rodgher ${ }^{1}$; Cristiane Yumi Koga Ito ${ }^{1}{ }^{(D}$; \\ Vivian Silveira dos Santos Bardini1 ${ }^{10}$; Luis Miguel Gutiérrez Klinsky² ${ }^{2}$ \\ ${ }^{1}$ Departamento de Engenharia Ambiental. Instituto de Ciência e Tecnologia de São José dos Campos. \\ Universidade Estadual Paulista Júlio de Mesquita Filho (UNESP), Rodovia Presidente Dutra, Km 137,8, \\ CEP: 12247-004, São José dos Campos, SP, Brazil. E-mail: suzelei.rodgher@unesp.br, \\ cristiane.koga-ito@unesp.br, vivian.bardini@unesp.br \\ ${ }^{2}$ Departamento de Análise de Infraestrutura. Banco de Desenvolvimento da América Latina (CAF). Rua Isaac \\ Hanono Missri, n 2000, Código Postal: 0832, Panamá. E-mail: lgutierrez@caf.com \\ *Corresponding author. E-mail: fabiana.fiore@unesp.br
}

\begin{abstract}
Among the waste produced daily by communities are those resulting from the treatment of water for public supply, with local specificities that reflect the characteristics and uses of the land. Despite the continuous generation and inadequate disposal still current in Brazil, there is little information on these residues. The data related to the composition of these sludges are essential for the study of alternatives for beneficial uses and for determining the risks to the environment and human health from inadequate disposal. It is in this context that the present study was developed, with the objective of identifying the physical-chemical characteristics of sludge produced in water treatment plants (WTPs) and of verifying the presence of these elements in the waters of the source used for supply. Such research was carried out through a case study in two WTPs in the state of São Paulo that perform surface abstraction. Therefore, in each of the WTPs, samples of densified sludge, representative of the dry and rainy periods, were characterized. The chemical findings of the sludge have been compared to the historical series of a decade of monitoring of the water quality of the sources of these WTPs. Among the main results, concentrations above the reference limits for the inert residues of aluminum, iron, manganese and barium in sludge are highlighted, as well as the existence of iron and manganese in the raw water collected and the variations in the concentrations of iron, sodium and manganese in the sludge due to the climatic conditions.
\end{abstract}

Keywords: physicochemical parameters, sludge of WTS, solid waste, water quality.

\section{Qualidade de água superficial e geração de lodos em estações de tratamento de água}

\section{RESUMO}

Dentre os resíduos cotidianamente produzidos pelas comunidades estão aqueles decorrentes do tratamento das águas para o abastecimento público, com especificidades locais que refletem as características e os usos da terra. A despeito da contínua geração e da disposição inadequada ainda vigente no Brasil, existem poucas informações sobre esses resíduos. Os dados 
relacionados à composição desses lodos são essenciais para o estudo de alternativas de usos benéficos e para a determinar os riscos ao meio ambiente e à saúde humana da disposição inadequada. É nesse contexto que o presente estudo foi desenvolvido com o objetivo de identificar as características físico-químicas de lodos produzidos em estações de tratamento de água (ETAs) e de verificar a presença desses elementos nas águas dos mananciais utilizados para o abastecimento. Tal pesquisa foi realizada por meio de estudo de caso em duas ETAs do estado de São Paulo que realizam captação superficial. Para tanto, em cada uma das ETAs foram caracterizadas amostras de lodos adensados, representativas dos períodos seco e chuvoso. Os achados químicos dos lodos foram equiparados à série histórica, de uma década de monitoramento, de qualidade das águas dos mananciais dessas ETAs. Dentre os principais resultados destacam-se as concentrações acima dos limites de referência para os resíduos inertes de alumínio, ferro, manganês e bário em lodos; a existência de ferro e manganês nas águas brutas captadas e a variação das concentrações de ferro, sódio e manganês nos lodos em decorrência da condição climática.

Palavras-chave: lodo de ETA, parâmetros físico-químicos, qualidade de águas, resíduos sólidos.

\section{INTRODUCTION}

In Brazil, the water supply is an essential service under public responsibility and aims to ensure adequate conditions of basic sanitation in the national territory. In $2017,90 \%$ of the population inhabited urban centers and the mean per capita demand of water was approximately 160 liter/day. Superficial catchment provides the water resources of $56.45 \%$ of Brazilian cities. However, in order to accomplish the current guidelines of potability, in most of the cases water is treated in complete cycle stations that generate sludge (Brasil, 2007; 2019).

The generation of sludge in water treatment stations can be estimated by empirical formulas that are dependent on the physicochemical characteristics of water and products used in the process. The dynamic anthropic use of spaces and interactions between the environments cause distortions between the estimated values and real generated volumes. Considering the generation of sludge of approximately 1 to $3 \%$ of treated water, according to Messias (2013), in Brazil the generation of sludge per day would be around 260,000 to $800,000 \mathrm{~m}^{3}$.

Water treatment station sludges contain inorganic materials (silt, sand, clay and hydrated metallic oxides) and organics (including pathogenic microorganisms) that are commonly found in the sources of raw water capture, and also products used in the water treatment, such as coagulants, coagulation auxiliary polymers and chalk. There are also several studies that pointed out the presence of metals (Ling et al., 2017, Godoy et al., 2020)

In Brazil, WTP sludges are classified as solid residuals of public services of basic sanitation. Their management is under the responsibility of the institution that generates them and must be supported by a plan of management approved by the license agency, in accordance with the current residuals management plan. According to instruction \#13/2012 from Brazilian Institute of the Environment and Renewable Natural Resources, WTP sludge are non-dangerous residuals, but the specific characterization is part of the minimal content of management plan of each unit (ABNT, 2004; Brasil, 2010).

The inadequate discard of sludge in the Brazilian territory is known; however, these residuals were not considered in the preliminary version of the National Solid Residuals Management Plan (NSRM). In the State of São Paulo, the absence of data related to the production and management of sludge, mentioned in the residuals management plan, did not represent a problem to the establishment of a goal of recycling the sludge for benefic uses, according to the principles of cleaner production. The establishment of this aim meets the guidelines of solid residuals management established by (NSRM), as follows: adoption of serial 
strategies to guarantee the non-generation, reduction, reuse, recycling and treatment of reverse solid residuals and the environmentally adequate final discard only for wastes (Brasil, 2010; 2012; São Paulo, 2014).

In WTPs, reducing the generation of sludge requires the catchment of less polluted water, development of new technologies and the use of more efficient and cheap reagents, since, according to Zhou et al. (2015), the inter recirculation of WTP sludges is limited due to the risk of water contamination. Regarding the recycling of these sludges, several alternatives of benefic uses have been pointed out as promising.

Among the most studied benefic uses, some can be cited: composting, incorporation in ceramic bricks and non-structural concrete blocks; application in soil for the recovery of degraded areas; for the conditioning and correction of soil $\mathrm{pH}$; in mixtures with natural soils for use in geotechnical work in landfills; and for production of coagulants (Turner et al., 2019; Wolowiec and Bajda, 2017; Gomes et al., 2019; Howells et al., 2018).

According to Ackah et al. (2018), the composition of WTP sludges is the main determinant of their beneficial use. In Brazil, there is no current public data on the composition of these residues. The most recent information on this subject is found in studies on the presence of contaminants in specific station locations (Wasserman et al., 2018) and on the viability of the beneficial use of the material, such as substitution of materials for concrete production (Buselatto et al., 2019), mortars (Alexandre and Luz, 2020; Godoy et al., 2020) blocks (Santos and Campos, 2018 ); geotechnical applications (Montalvan, 2016); and in mixtures to improve energy potential (Carneiro et al., 2020).

In Brazil, the control of the physical-chemical and biological characteristics of the raw water captured is compulsorily carried out by the operators of the WTPs, as determined by the Ministry of Health (Brasil, 2017). These data are usually used to control water potabilization processes but are not yet commonly related to sludge production. It is in this context that the present research was carried out, with the objective of identifying the physical-chemical characteristics of sludge produced in different climatic conditions, in WTPs located in the state of São Paulo (SP), and to evaluate the presence of sludge contaminants in the water sources used for potabilization.

\section{MATERIALS AND METHODS}

This work is an exploratory case study that used quantitative data for performing comparative classifications. Considering the need of preserving the identity of the studied WTPs according to the research cooperation agreement, they were identified as WTP1 and WTP2. Information regarding their operational characteristics and products were described by the operation technical staff of the WTPs. WTP 1 and 2 are located in different metropolitan regions of the state of São Paulo and are responsible for the potabilization of about $20 \mathrm{~m}^{3} / \mathrm{s}$ of water. Both treat water in a complete cycle (conventional) that contains the stages of coagulation, flocculation, decantation, filtration, disinfection (pre and post treatment), fluoridation and $\mathrm{pH}$ correction.

In WTP 1, the raw water is captured in a large reservoir that has interconnection with other sources to guarantee the volume of water supplied. In it, liquid aluminum sulfate, polyaluminium chloride, ferric chloride or ferric sulfate are used alternatively as coagulants of the solids present in the raw waters. For $\mathrm{pH}$ correction, lime is also used, and for disinfection, liquid and gaseous chlorine is used in the form of hypochlorite. Fluorosilicic acid is also added for fluoridation.

WTP 1 can also possibly use auxiliary chemicals, such as polyelectrolyte to increase treatment efficiency, activated carbon to remove the taste and odor from raw water and potassium permanganate for the oxidation of iron and manganese, in cases where special conditions of raw water quality are detected. At this station, the generated sludge is sent to an 
equalization tank for homogenization and application of polymers before being drained. After centrifugation, sludge cakes with up to $22 \%$ moisture content are formed.

In WTP 2, the waters are captured directly from the surface water resource and, before the coagulation stage, they pass through the grit chamber. As a coagulating agent, WTP uses ferric chloride. Granular quicklime is used for the correction of $\mathrm{pH}$, chlorine is used for disinfection and fluosilicic acid is used for fluoridation.

For the physicochemical analyses of the sludges from the WTPs, two samplings were performed, the first in October 2018, and the second in August 2019. Considering the data of a historic series of rainfall in the city of São Paulo, collected at the National Institute of Meteorology stations 83856 and 83781, the samples were collected in the periods of higher rates of rainfalls in 2018 and in the dry period of 2019. Considering these data, this study was performed with sludge samples that represent the rainy and dry periods, respectively.

The samples were collected after centrifugation, as this is one of the operational steps in the evaluated WTS. Sludges were characterized by the evaluation of raw mass, leachate and solubilized extract. The analyses were performed by different laboratories accredited by The National Institute of Metrology, Standardization and Industrial Quality, according to standards 10.004, 10.005 and 10.006 of Brazilian Association of Technical Standards (ABNT, 2004). Table 1 shows the analytic methods adopted by the laboratories for the analyses of organic and inorganic parameters evaluated in the present study. All methods adopted are regulated in Brazil (ABNT, 2004).

Table 1. Analytic methods adopted for the analyses of physicochemical parameters.

\begin{tabular}{lcc}
\hline \multirow{2}{*}{ Parameters } & \multicolumn{2}{c}{ Analytic methods } \\
\cline { 2 - 3 } & Dry period & Rainy period \\
\hline Sample color & visual & -- \\
Corrosivity & NBR 10004 (ABNT, 2004) & MELAB 45 2014 \\
Reactivity & -- & NBR 14598 (ABNT, 2012) \\
Bulk density & POP 173 Ed. 8 & NBR 14598 (ABNT, 2012) \\
Physic state & -- & NBR 14598 (ABNT, 2012) \\
Phenol & Visual & MELAB 45 2014 \\
pH & EPA 9065 (USEPA, 1986) & -- \\
Dry and solid content & NBR 10004 (ABNT, 2004) & SMEWW 4500-H+ B 2012 \\
Moisture & NBR 6457 (ABNT, 2016) & SMEWW 2540 B.E 2012 \\
Sulfide & NBR 6457 (ABNT, 2016) & MELAB 45 2014 \\
Barium & -- & SMEWW 4500 S2- D 2012 \\
Cadmium & SMEWW 3120B Ed. 22 & SMEWW 3111 B.C.D 2012 \\
Lead & -- & SMEWW 3111 B.C.D 2012 \\
Fluoride & -- & SMEWW 3111 B.C.D 2012 \\
Aluminum & POP 067 Ed. 13 & SMEWW 4500-F C 2012 \\
Chloride & SMEWW 3120B Ed. 22 & SMEWW 3500-Al B 2012 \\
Ion & SMEWW 4500B Ed. 22 & SMEWW 4500-Cl C 2012 \\
Manganese & SMEWW 3120B Ed. 22 & SMEWW 3111 B.C.D 2012 \\
Sodium & SMEWW 3120B Ed. 22 & SMEWW 3111 B.C.D 2012 \\
\hline
\end{tabular}

Data on the composition of WTP sludges that showed quantifiable values were individually shown for WTP1 and 2 and were compared to reference values from technical guides from Brazil 10.004 (ABNT, 2004) as well as their mean values. Classifications regarding the risks of these sludges were copied from the technical report that was based on the data shown in this study and on the analyses of pesticides also determined by technical guides from Brazil 10.004 (ABNT, 2004). 
Data on the analyses of raw water, including all the chemical elements identified in the composition of the sludge, was found for both WTSs. The historic data regarding the quality of water in the sources was also provided by the operational staff for the range between 2008 and 2018. According to this information, samples were collected according to Method 1060 described in Standard Methods for the Examination of Water and Wastewater (APHA et al., 1998) and the analyses were performed in the laboratory of the responsible agency, in accordance with the specific methods determined by the U.S. Environmental Protection Agency (USEPA), the Brazilian Association of Technical Standards and the American Public Health Association (APHA) for each one of the parameters in accordance with Brazilian law (Brasil, 2017).

The historic data of the sources selected for this study were compared to the quality standard adopted for Classes 1 and 2 of Resolution 357 (CONAMA, 2005), that were considered as references for the quality conditions of human supply with simplified or conventional treatment. It is worth noting that, in the State of São Paulo, the catchment of water for human supply is forbidden in hydric resources with quality below the adopted standards (São Paulo, 1997).

\section{RESULTS AND DISCUSSION}

\subsection{Physicochemical composition of sludge}

The evaluated sludges were found in a pasty physical state, brown in color and did not present characteristics of corrosivity, reactivity or flammability. There were also no detectable concentrations of pesticides in the solubilized and leached extracts. Table 2 shows the synthesis of the values found in the evaluation of the sludge from WTPs.

Table 2. Physicochemical composition of sludge from WTPs 1 and 2.

\begin{tabular}{|c|c|c|c|c|c|c|c|c|c|c|c|c|c|}
\hline \multirow{3}{*}{ Parameter } & \multirow{3}{*}{ Reference value } & \multirow{3}{*}{ Unit } & \multicolumn{5}{|c|}{ WTP 1} & \multicolumn{6}{|c|}{ WTP 2} \\
\hline & & & \multicolumn{3}{|c|}{ Dry season } & \multicolumn{2}{|c|}{ Rainy Season } & \multicolumn{3}{|c|}{ Dry season } & \multicolumn{3}{|c|}{ Rainy Season } \\
\hline & & & G.M. & Leac. & Sol. & G.M. Leac. & Sol. & G.M. & Leac. & Sol. & G.M. & Leac. & Sol. \\
\hline Phenol & -- & $\mathrm{mg} / \mathrm{Kg}$ & 6.65 & & & & & & & & & & \\
\hline $\mathrm{pH}$ & $2-12.5$ & $\mathrm{UpH}$ & 6.25 & & & 6.45 & & 7.66 & & & 7.66 & & \\
\hline Bulk density & -- & $\mathrm{g} / \mathrm{cm}^{3}$ & & & & 0.96 & & & & & 1.21 & & \\
\hline Dry solids content & -- & $\%$ & 15.38 & & & 17 & & 29.82 & & & 29.9 & & \\
\hline Moisture & -- & $\%$ & 84.62 & & & 83 & & 70.18 & & & 70.1 & & \\
\hline Sulfide & 500 & $\mathrm{mg} / \mathrm{Kg}$ & & & & 302 & & & & & & & \\
\hline Barium & $\begin{array}{l}70 \text { leac. } \\
0.7 \text { sol. }\end{array}$ & $\mathrm{mg} / \mathrm{L}$ & & 0.36 & 0.03 & & & & 0.473 & & & 7.72 & 7.59 \\
\hline Cadmium & $\begin{array}{c}0.5 \text { leac. } \\
0.005 \text { sol. }\end{array}$ & $\mathrm{mg} / \mathrm{L}$ & & & & & & & & & & 0.02 & \\
\hline Lead & $\begin{array}{l}1 \text { leac. } \\
0.01 \text { sol. }\end{array}$ & $\mathrm{mg} / \mathrm{L}$ & & & & & & & & & & 0.16 & \\
\hline Fluoride & $\begin{array}{c}150 \text { leac. } \\
1.5 \text { sol. }\end{array}$ & $\mathrm{mg} / \mathrm{L}$ & & 0.4 & & & & & 0.205 & & & & 1.1 \\
\hline Aluminum & 0.2 & $\mathrm{mg} / \mathrm{L}$ & & & 0.08 & & & & & & & & 0.49 \\
\hline Chloride & 250 & $\mathrm{mg} / \mathrm{L}$ & & & 53,8 & & 52.5 & & & 21.9 & & & 20.9 \\
\hline Total iron & 0.3 & $\mathrm{mg} / \mathrm{L}$ & & & 1.73 & & 4.92 & & & 0.53 & & & 18.21 \\
\hline Total manganese & 0.10 & $\mathrm{mg} / \mathrm{L}$ & & & 10.75 & & 1.94 & & & 0.94 & & & 0.22 \\
\hline Sodium & 200 & $\mathrm{mg} / \mathrm{L}$ & & & 3.18 & & 9.99 & & & 1.96 & & & 19.38 \\
\hline
\end{tabular}

Where: G.M. corresponds to the results of the analyses in gross mass; Leac. in leached sample and Sol. those performed in solubilized samples. The blank cells correspond to parameters not detected.

The sludge sampled from WTPs 1 and 2, in the dry and rainy seasons, was characterized according to NBR 10.004 (ABNT, 2004) as non-inert non-hazardous waste (Class II-A), in accordance with IN-IBAMA 13/2012 (IBAMA, 2012). The concentrations of inorganic 
compounds observed when the samples were solubilized supported the characterization of the residues as non-inert. Barium, aluminum, iron and manganese were detected and suggest that care must be taken regarding the handling and destination of the sludge from WTPs. The presence of aluminum, iron and manganese in sludge from WTPs was reported in sludge that used the same coagulants adopted by WTPs 1 and 2; however, in the present study, the concentrations of aluminum verified were significantly lower than the minimal reference reported in literature (Turner et al., 2019; Wolowiec et al., 2019; Do Amaral Sobrinho et al., 2018). The excessive concentration of barium in the solubilized sludge from WTP 2 is also worth mentioning, since this element, when soluble, can cause harmful effects to human health (ATSDR, 2007). It should be noted that for the sludge sample of WTP 2, in dry weather, the results of barium in the solubilized sample were below the limit of quantification of the method, more consistent with the quality of raw water in the 10-year historical series in which this metal was not observed.

When comparing the values obtained for the dry and rainy seasons, it appears that, for the $\mathrm{pH}$, humidity, dry solids and chloride parameters, the values do not change. The iron and sodium parameters have their concentrations increased in the rainy season, whereas manganese had its average concentration reduced by about five times in the rainy season. The increase in the concentration of iron is associated with the increased supply of coagulants necessary to remove the turbidity of the captured surface water. Despite the increase of the sodium concentration in the sludge of about ten times in WTP 2, the values found in the rainy season are lower than the reference values for Class II. For these WTPs, the manganese concentrations in the sludge are higher than the reference values for Class II, even in the dry period. The reduction of the average concentration in the rainy season of about five times is indicative that the contribution of the contaminant must originate from anthropic activities with constant load, regardless of climatic conditions. The increase in the concentration of iron and sodium in the rainy season was also observed by Ribeiro (2007) when evaluating sludge from WTPs in the municipality of Itabirito (MG).

The $\mathrm{pH}$ and iron values reported by Ahmad et al. (2016), in water treatment plants in India are similar to the average values verified in WTPs 1 and 2. However, the elements manganese and sodium were found in concentrations two and six times higher than those verified by the authors. It is worth noting that the studied sludge has a solids concentration six times higher than that used in the 2016 survey. Other chemical elements, such as barium and arsenic, were found in high concentrations in sludge from WTPs in India compared to values obtained in the present study (Ahmad et al., 2016).

Considering the values reported by Turner et al. (2019), the $\mathrm{pH}$, humidity, manganese and iron parameters identified in WTPs 1 and 2 are within the concentration range verified in other studies. The lead and aluminum parameters in the sludge of these WTPs are significantly lower. Compared to the composition data systematized by Wolowiec et al. (2019), which segregates the values as a function of aluminum and iron coagulants used in the water potabilization process, the sludge from WTP 1 has an aluminum concentration 600 times lower than the minimum value reported in previous research and the sludge from WTP 2 has a concentration of iron and aluminum about 80 and 4 times lower, respectively.

The data obtained in the present research were also compared to the values presented in the final report of the PROSAB project (1999), since this study still serves as a reference for most of the work carried out in the country on the subject. From this analysis, it is possible to verify that:

- the upper limit of basicity of $\mathrm{pH}$ is about $10 \%$ higher;

- the aluminum concentration is $0.15 \%$ times the lowest value reported at the time; 
- cadmium and lead are less recurrent in the samples and in no case do they exceed $20 \%$ of the reference concentration;

- chloride showed values higher than those recorded at the time for WTP 1, by about 70\%;

- the total iron sampled, which is still present in the sludge from WTP s, has an average concentration of $0.5 \%$ of the lowest value reported at the time;

- the concentration of manganese verified in WTP 1, in the dry period is higher than the highest value previously identified;

- the average sodium concentration does not reach $30 \%$ of the value reported at the time as the lowest value.

\subsection{Quality of the water source and the composition of the sludge from WTPs}

Among the chemical parameters verified in detectable concentrations for the sludge, only the manganese and iron parameters were identified in the historical series available by the WTP 1 operational team. The graphs shown in Figures 1 and 2 show how the concentration of these elements occurs in the source of that WTP, throughout the evaluated decade.

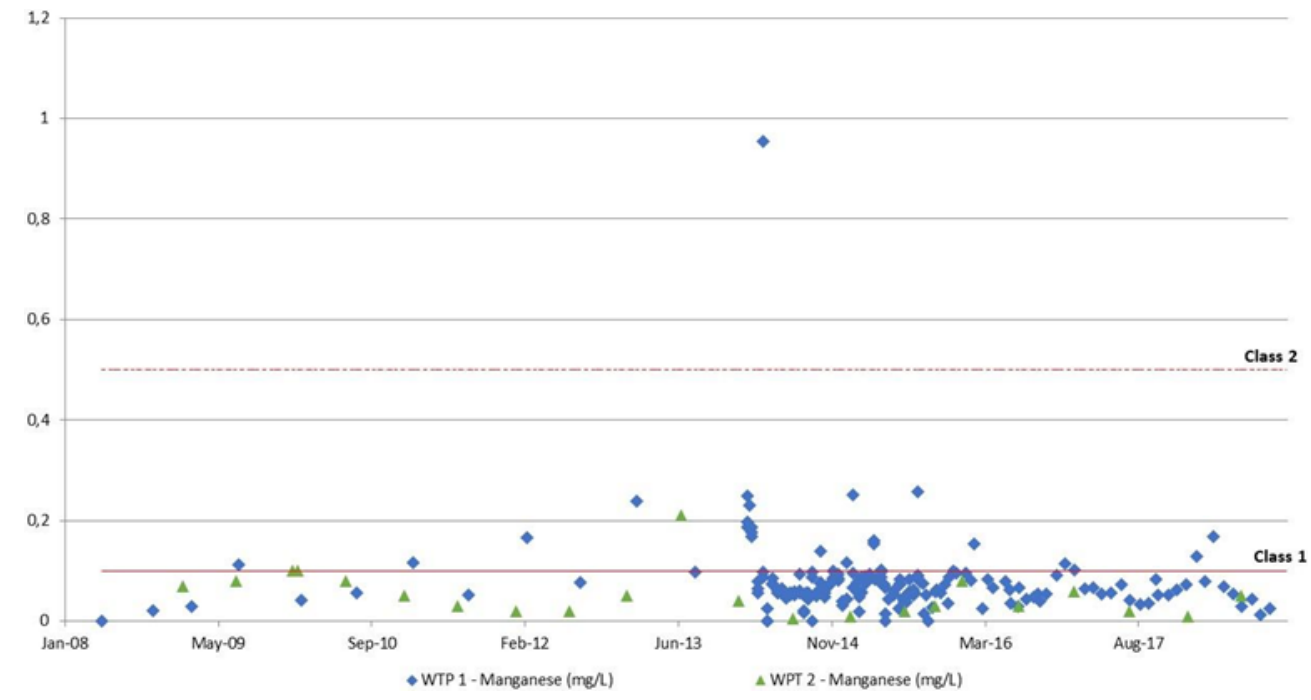

Figure 1. Manganese concentration in raw water from WTP 1 and 2.

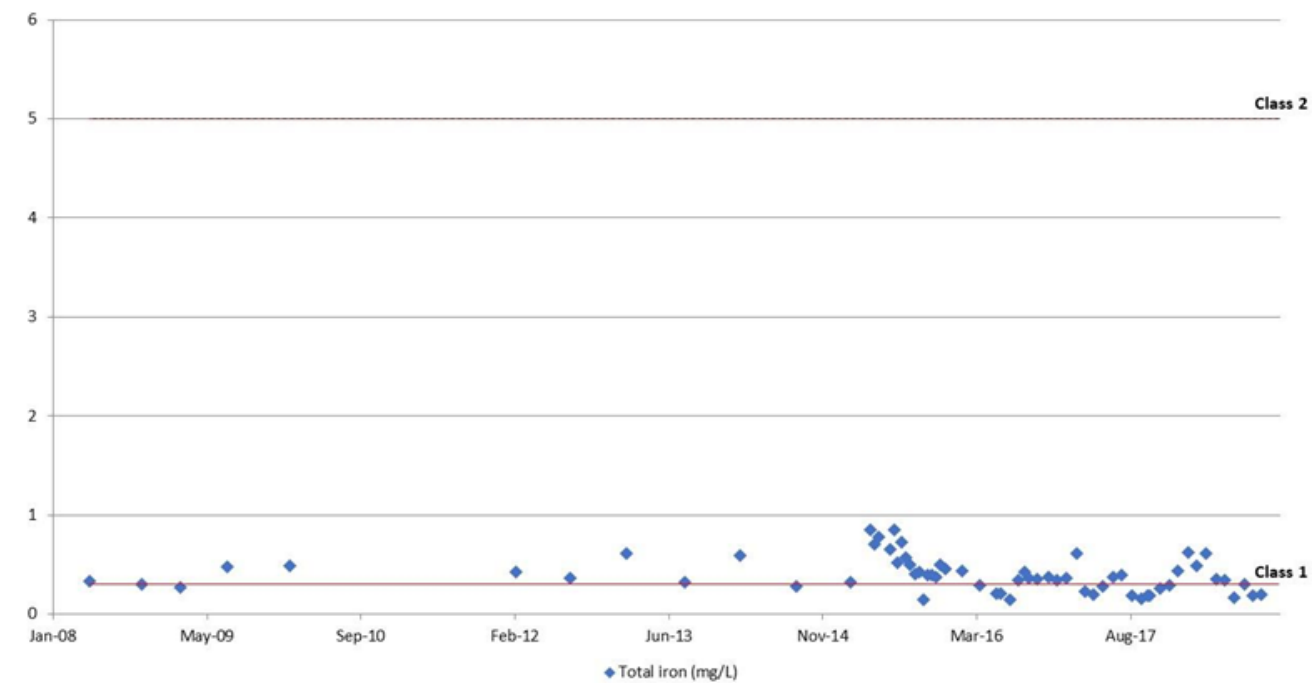

Figure 2. Total iron concentration in raw water from WTP 1. 
According to the raw water quality data, Manganese already occurs in the collected waters, in some cases, in limits higher than those established for Class 1. Considering the average value of manganese in water in the evaluated period $(0.04 \mathrm{mg} / \mathrm{L})$, and its concentration in the solubilized sludge samples, it is possible to infer that for WTP 1, in the dry period, the element was concentrated about 270 times, and in the rainy period, approximately 50 times.

For the iron that also occurs in raw water supplied by WTP 1 , in most cases in concentrations above the limits of Class 1, the excessive concentrations of the element in sludge samples, in both periods, can be associated with concentrations of this element in raw water, since during the research period no iron-based coagulant was used for water potabilization.

In the raw waters treated by WTP 2, it was found that in less than $10 \%$ of the analyses the concentration of cadmium exceeded the limits established as a reference for Class 1 waters; but in these cases, occurring in both rainy and dry periods, the maximum concentration found was $30 \%$ of the Class 2 reference value. If the cadmium values observed in the raw waters are compared to the concentrations verified in the leached sample of the sludge in the rainy season, it appears that it was 10 times more concentrated.

Despite the fact that the use of aluminum sulphate or chloride in the operational process of WTP 2 was not declared, the aluminum concentration evaluated in the sludge exceeded the reference value established for the parameter for the solubilized sample. However, since the element concentrations were not measured in the raw water collected, it cannot be said that its occurrence in the sludge is due to the use of coagulants.

The occurrence of sodium in the raw waters of this ETA was evaluated only twice, in 2009, and concentrations were found below $10 \mathrm{mg} / \mathrm{L}$; this parameter does not have quality limits established according to the classes in freshwaters. Considering the average of the analyses in raw water and the results of the sludge samples, it appears that the sodium concentrations were diluted about 4 times for the sludge during the dry season and concentrated about twice in the rainy season. Considering the small number of samples of raw water, these assertions have more significant errors than the other parameters evaluated.

In the available historical series, total Iron was measured only four times and showed concentrations of $1.19 ; 2.63 ; 0.81$ and $1.17 \mathrm{mg} / \mathrm{L}$. These values are higher than the Class 1 limits, but lower than those established as Class 2 quality criteria. For WTP 2, the percentages of the element cannot be directly related to those verified in the sludge, since in the coagulation process uses ferric chloride.

The concentrations of the manganese and chloride elements identified in the historical series, available by the WTP 2 operational team, are shown in Figures 1 and 3.

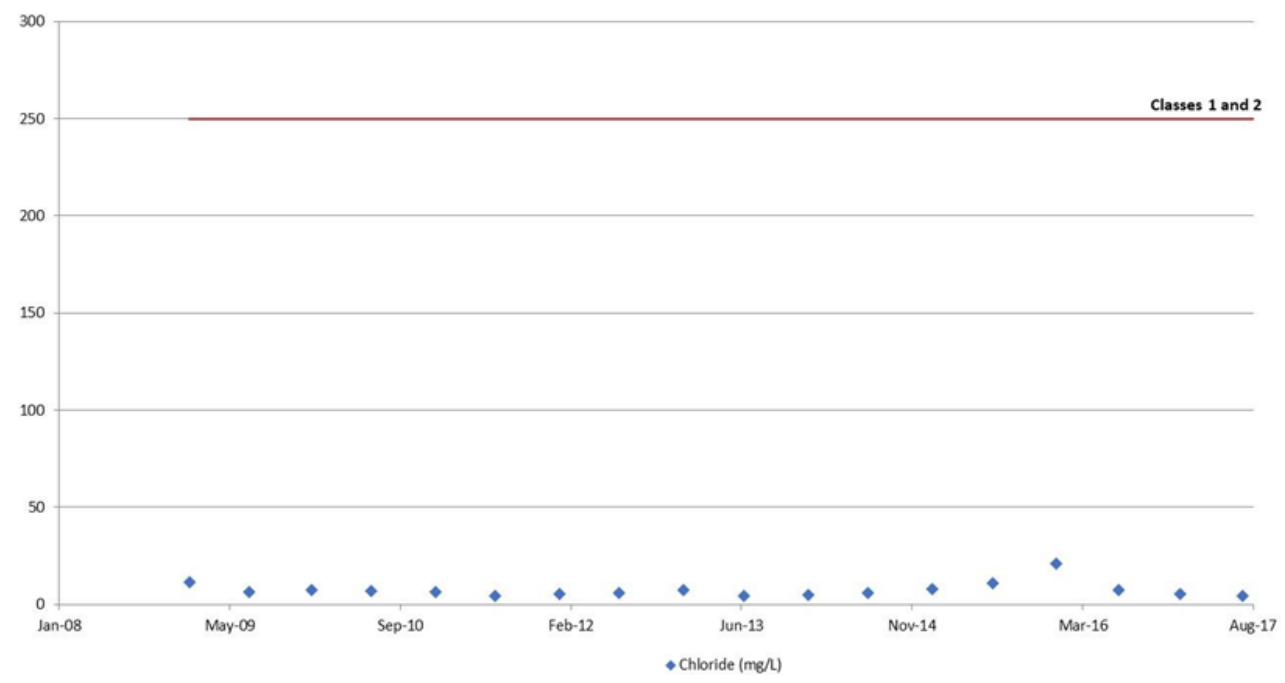

Figure 3. Chloride concentration in raw water from WTP 2. 
As can be seen, manganese was sampled less frequently for this season. However, it appears that its concentrations in these analyses are mostly within the limits established as a quality reference for Class 1 , so the Class 2 limit $(0.5 \mathrm{mg} / \mathrm{L})$ was not even shown in the graph. Considering the average concentration of the element in raw water in the evaluated period, and the concentration verified in the solubilized samples of the sludge, it can be inferred that the water treatment concentrates this pollutant in about 13 times in the dry period and approximately 3 times in the rainy season.

Also for the chloride element, sampling was not carried out frequently, but its concentrations in raw water are low when compared to the single reference value established for Classes 1 and 2, of $250 \mathrm{mg} / \mathrm{L}$. Considering the average concentration of the element in raw water in the evaluated period, and the concentration verified in the sludge, it can be inferred that the element was twice more concentrated in solubilized samples of sludge.

From the analysis of the databases provided by the operational team of the WTPs under study, it is possible to verify that they evaluate a greater number of parameters than those legally established in Brazil for the quality control of the water sources. Thus, it is understood that the continuity of this study and the development of a tool that correlates the characteristics of raw water and inputs used in WTPs with the classification of sludge generated by them can provide greater security for the management and disposal of sludge produced in different WTPs, including the reduction of cost reduction associated with frequent classification analyses.

\section{CONCLUSIONS}

According to the results, it could be concluded that the water treatment plants with surface capture evaluated in this study generate sludge that keep the chemical characteristics of the source water. In these WTPs, it is possible to verify that the sludge produced in rainy periods has higher concentrations of iron and sodium and that the concentration of manganese is minimized.

The results suggest that the plants that capture water with chemical elements above the reference values for Class 1 generate sludge with the presence of these same elements above the reference values for inert waste. It also suggests that current water potabilization processes are more efficient in the use of coagulants and, therefore, produce sludge with less potential for contamination.

\section{ACKNOWLEDGEMENTS}

This work was supported by São Paulo Research Foundation - FAPESP (Proc.: 2018/00099-0).

\section{REFERENCES}

ABNT. NBR 10.004: Resíduos sólidos - Classificação. Rio de Janeiro, 2004.

ABNT. NBR 14.598: Produtos de petróleo - Determinação do ponto de fulgor pelo aparelho de vaso fechado Pensky-Martens. Rio de Janeiro, 2012.

ABNT. NBR 6457: Amostras de solo — Preparação para ensaios de compactação e ensaios de caracterização. Rio de Janeiro, 2016.

ACKAH, L. A.; GURU, R.; PEIRAVI, M.; MOHANTY, M.; MA, X.; KUMAR, S.; LIU, J. Characterization of Southern Illinois Water Treatment Residues for Sustainable Applications. Sustainability, v. 10, n. 5, 2018. https://doi.org/10.3390/su10051374 
AHMAD, T.; AHMAD, K.; ALAM, M. Characterization of Water Treatment Plant's Sludge and its Safe Disposal Options. Procedia Environmental Sciences, v. 35, p. 950- 955, 2016. https://dx.doi.org/10.1016/j.proenv.2016.07.088

ALEXANDRE, E; LUZ, C. A. Partial replacement of CPV-ARI cement by water treatment plant sludge (WTS). Matéria, v. 25, n. 1, 2020. http://dx.doi.org/10.1590/s1517707620200001.0912

APHA; AWWA; WEF. Standard Methods for the Examination of Water and Wastewater. 20. ed. Washington, 1998.

BRASIL. Ministério da Saúde. Portaria n. 05, de 28 de setembro de 2017. Consolidação das normas sobre as ações e os serviços de saúde do Sistema Único de Saúde. Diário Oficial [da] União: seção 1, Brasília, DF, n. 190, supl. p. 516-531, 03 de out. de 2017.

BRASIL. Ministério do desenvolvimento Regional. Sistema Nacional de Informações sobre Saneamento. Diagnóstico dos Serviços de Água e Esgotos - 2017. Brasília, 2019.

BRASIL. Presidência da República. Lei no 11.445, de 5 de janeiro de 2007. Estabelece as diretrizes nacionais para o saneamento básico; cria o Comitê Interministerial de Saneamento Básico; altera as Leis nos 6.766, de 19 de dezembro de 1979, 8.666, de 21 de junho de 1993, e 8.987, de 13 de fevereiro de 1995; e revoga a Lei ${ }^{\circ} 6.528$, de 11 de maio de 1978. Diário Oficial [da] União, Brasília, DF, 08 jan. 2007.

BRASIL. Presidência da República. Lei n. 12.305, de 2 de agosto de 2010. Institui a Política Nacional de Resíduos Sólidos; altera a Lei no 9.605, de 12 de fevereiro de 1998; e dá outras providências. Diário Oficial [da] União: seção 1, Brasília, DF, 03 ago. 2010.

BRASIL. Presidência da República. Plano Nacional de Resíduos Sólidos - versão preliminar. $\quad$ Brasília, 2012. Available at: http://www.sinir.gov.br/documents/10180/12308/PNRS_Revisao_Decreto_280812.pdf/ e183f0e7-5255-4544-b9fd-15fc779a3657. Access: Jan. 2020.

BUSELATTO, D. M.; WENZEL, M. C.; DA ROCHA, G. H. et al. Use of water treatment sludge (WTS) as fine aggregate in concretes: evaluation of physical-mechanical properties. Matéria, v. 24, n. 1, 2019. https://doi.org/10.1590/s1517-707620190001.0645

CARNEIRO, M.; BILOTTA, P.; MALUCELLI, L. C. et al. Sludge and scum blends from water and sewage treatment plants for energy recovering toward a circular economy perspective. International Journal of Environmental Science and Technology, v. 17, p. 3847-3856, 2020. https://doi.org/10.1007/s13762-020-02727-8

CONAMA (Brasil). Resolução $\mathrm{n}^{\circ} 357$ de 17 de março de 2005. Dispõe sobre a classificação dos corpos de água e diretrizes ambientais para o seu enquadramento, bem como estabelece as condições e padrões de lançamento de efluentes, e dá outras providências. Diário Oficial [da] União: seção 1, Brasília, DF, n. 053, p. 58-63, 18 mar. 2005.

Do AMARAL SOBRINHO, N. M. B.; CEDDIA, M. B.; ZONTA, E. et al. Spatial variability and solubility of barium in a petroleum well-drilling waste disposal area. Environmental Monitoring and Assessment, v. 190, n. 228, 2018. https://doi.org/10.1007/s10661-018$6566-\mathrm{x}$ 
GODOY, L. G. G. D.; ROHDEN, A. B.; GARCEZ, M. R.; Da DALT, S.; BONAN GOMES, L. Production of supplementary cementitious material as a sustainable management strategy for water treatment sludge waste. Case Studies in Construction Materials, v. 12, 2020. https://doi.org/10.1016/j.cscm.2020.e00329

GOMES, S. D. C.; ZHOU, J. L.; LI, W.; LONG, G. Progress in manufacture and properties of construction materials incorporating water treatment sludge: A review. Resources, $\begin{array}{llllll}\text { Conservation and Recycling, } & \text { v. 145, p. }\end{array}$ https://doi.org/10.1016/j.resconrec.2019.02.032

HOWELLS, P. A.; LEWIS, J. S.; BEARD, B. D.; OLIVER, W. I. Water treatment residuals as soil amendments: Examining element extractability, soil porewater concentrations and effects on earthworm. Ecotoxicology and Environmental Safety, n. 162, p. 334-340, 2018. https://doi.org/10.1016/j.ecoenv.2018.06.087

IBAMA (Brasil). Instrução Normativa $n^{\circ} 13$ de 18 de dezembro de 2012. Diário Oficial [da] União, seção 1, 20 dez. 2012.

LING, Y. P. et al. Evaluation and reutilization of water sludge from fresh water processing plant as a green clay substituent. Applied Clay Science, v. 143, p. 300-306, 2017. https://doi.org/10.1016/j.clay.2017.04.007

MESSIAS, T. G. Avaliação Ecotoxicológica de Lodo Gerado por Estação de Tratamento de Água. 2013. 163 p. Tese (Doutorado) - Programa de Pós Graduação em Ciências, Centro de Energia Nuclear na Agricultura, Universidade de São Paulo, Piracicaba, 2013.

MONTALVAN, E. L. T. Investigação do comportamento geotécnico de misturas de solo arenoso com lodo da estação de tratamento de água do município de Cubatão, SP. 2016. Dissertação (Mestrado) - Escola Politécnica, Universidade de São Paulo, São Paulo, 2016.

PROSAB. Noções gerais de tratamento e disposição final de lodos de estações de tratamento de água. Rio de Janeiro: ABES, 1999.

RIBEIRO, F. L. M. Quantificação e caracterização química dos resíduos da ETA de Itabirito - MG. 2007. 133f. Dissertação (Mestrado) - Universidade de Ouro Preto, Ouro Preto, 2007.

SANTOS, S. S. A.; CAMPOS, V. P. Use of Water Treatment Plant Solid Residues (Sludge) as Raw Material to Manufacture Construction Elements. Revista Virtual de Química, v. 10, n. 2, p. 273-287, 2018. https://dx.doi.org/10.21577/1984-6835.20180021

SÃO PAULO (Estado). Secretaria do Meio Ambiente. Plano de resíduos sólidos do estado de São Paulo. São Paulo, 2014.

SÃO PAULO (Estado). Lei Estadual n. 9.866, de 28 de novembro de 1997. Dispõe sobre diretrizes e normas para a proteção e recuperação das bacias hidrográficas dos mananciais de interesse regional do Estado de São Paulo. Diário Oficial [do] Estado de São Paulo, seção 1, n. 230, 29 nov. 1997.

TURNER, T.; WHEELER, R.; STONE, A. et al. Potential Alternative Reuse Pathways for Water Treatment Residuals: Remaining Barriers and Questions-a Review. Water, Air, \& Soil Pollution, v. 230, n. 227, 2019. https://doi.org/10.1007/s11270-019-4272-0 
UNITED STATES. Agency for Toxic Substances and Disease Registry - ATSDR. Toxicological profile for barium and barium compounds. Atlanta, 2007. Available at: https://www.atsdr.cdc.gov/ToxProfiles/tp.asp?id=327\&tid=57. Access: 14 July 2020.

WASSERMAN, J. C. de; OLIVEIRA SILVA, L. de; PONTES, G. C. et al. Mercury contamination in the sludge of drinking water treatment plants dumping into a reservoir in Rio de Janeiro, Brazil. Environmental Science of Pollution Research, v. 25, p. 28713-28724, 2018. https://doi.org/10.1007/s11356-018-2899-9

WOŁOWIEC, M.; BAJDA, T. Current Stage of Knowledge Relating to the Use Ferruginous Sludge From Water Treatment Plants - a Preliminary Review of the Literature. Mineralogia, v. 48, n. 1-4, 2017. https://doi.org/10.1515/mipo-2017-0010

WOŁOWIEC, M.; KOMOROWSKA-KAUFMAN, M.; PRUSS, A.; RZEPA, G.; BAJDA, T. Removal of Heavy Metals and Metalloids from Water Using Drinking Water Treatment Residuals as Adsorbents: A Review. Minerals, v. 9, p. 487, 2019. https://doi.org/10.3390/min9080487

ZHOU, J.; HE, Z; YANG, Y; DENG, Y; TRINGE, S.G.; ALVAREZ-COHEN, L. Highthroughput metagenomic technologies for complex microbial community analysis: open and closed formats. Bio, v. 6, 2015. https://dx.doi.org/10.1128/mBio.02288-14 